\title{
The Impact of COVID-19 Pandemic and Commodities Prices on Booking.com Share Price
}

\author{
Meng-Chang Jong, Chin-Hong Puah*, Ann-Ni Soh \\ Faculty of Economics and Business, Universiti Malaysia Sarawak, Kota Samarahan, 94300, Malaysia
}

\begin{tabular}{l} 
A R T I C L E I N F O \\
\hline Article history: \\
Received: 16 September, 2020 \\
Accepted: 11 November, 2020 \\
Online: 10 March, 2021 \\
\hline
\end{tabular}

Keywords:

COVID-19 pandemic

Stock price

Tourism demand

Markov-switching approach

Hotel industry

\begin{abstract}
A B S T R A C T
This paper examines the impacts of the COVID-19 pandemic and selected commodity variables on Booking.com share price using the Markov-switching approach. Daily data spans from January 2017 through July 2020 are utilized in this study. Empirical evidence showed that COVID-19, international crude oil price, and gold price affected the Booking.com share price significantly. A positive relationship was detected between international crude oil price and gold price towards stock price whereas COVID-19 showed an inverse impact on stock price. The empirical findings evidenced a $1 \%$ increase in COVID19 cases adversely affecting the share price by $-0.27 \%$. Our findings also suggested that the potential of another wave of COVID-19 is relatively higher as the bounce back period was identified as 67 days. The filtered and smoothed probabilities signaled the Booking.com share price chronologically, and transition probabilities were identified. Six cycles were outlined, and the effectiveness of the Markov-switching approach in detecting vulnerable financial forecasting was demonstrated. The adequate dating evolution provided satisfactory input for policymakers, investors, and researchers to design and mitigate volatility in commodities and crises.
\end{abstract}

\section{Introduction}

COVID-19 was declared as a Public Health Emergency of International Concern by the World Health Organization (WHO) at the end of January 2020. It is now well established that COVID19 has greatly impaired the world economy, especially the tourism industry, with airplanes grounded, hotels closed, and restrictions placed on travel around the world. The World Tourism Organization (UNWTO) stated that the pandemic has placed the whole world on lockdown, and most destinations worldwide are still implementing COVID-19 related travel restrictions on international tourists. In [1], the author documented a double-digit $(-22 \%)$ decline in international tourists in 2020Q1, with $57 \%$ reduction in arrivals in March, which is equivalent to a total loss of 67 million international tourists and USD80 billion in tourism export revenues. The UNWTO foresees a total decline of $58 \%$ to $78 \%$ in international tourist arrivals in the year 2020, and a total of 100 to 120 million tourism jobs are directly at risk in the current scenario. This is by far the worst outcome since 1950 in the history of international tourism, a circumstance that will bring an abrupt end to a 10-year stretch of continuous growth following the financial crisis of 2009.

\footnotetext{
${ }^{*}$ Corresponding Author: Chin-Hong Puah, Faculty of Economics and Business, Universiti Malaysia Sarawak, 94300 Kota Samarahan, Malaysia. Email: chpuah@unimas.my

www.astesj.com
}

https://dx.doi.org/10.25046/aj060221
Due to the fast spread of the COVID-19 pandemic, most countries are responding quickly and effectively through international cooperation, particularly in terms of healthcare systems and financial support to protect people against the loss of their livelihoods. This step has moved closely to achieve several Sustainable Development Goals (SDGs), which are good health and well-being (Goal 3) and partnerships for the goals (Goal 17). Scientists around the world are working on potential treatments and vaccines to reduce the number of people infected and the number of deaths due to the pandemic and its related effects. Due to the outbreak of COVID-19, the UNWTO foresees the tourism industry facing an unprecedented challenge. The UNWTO accordingly hosted a virtual high-level meeting with key UN agencies, member states, and the private sector to work together as the Global Tourism Crisis Committee in responding to the emerging situation and to ensure that tourism is ready to lead recovery efforts.

Along with the rapid development of the tourism sector, the hospitality industry is one of the key pillars in receiving and serving tourists. Hotels are considered pivotal tourist facilities as one of the drivers of investment and employment in tourism [2]. Currently, the hospitality industry is facing an unprecedented challenge due to the worldwide lockdowns put in place by various countries. Booking.com is one of the world's leading digital travel 
platforms, operating on numerous well-known online platforms such as Agoda, Villas, and Kayak. With its significant contribution and diversify profile, the Booking.com share price was chosen for this study. Figure 1 reveals that the share price of Booking.com is sensitive not only to economic crises (dot-com bubble and subprime mortgage crisis) but also health crises (SARS outbreak and H1N1). These incidents have previously disrupted the travel industry, limiting the ability and willingness of tourists to travel to certain destinations, which result in a decline in demand that affects the travel industry as a whole. Due to the COVID-19 pandemic, the total revenue for Booking.com was USD2.3 billion in the first quarter of 2020, a decline of $19 \%$ from the preceding year. Furthermore, net cancellations were USD12.4 billion, marking a 50\% increase from over a year ago [3]. Thus, very little is known about the impact of COVID-19 on hotel stock returns. In addition, the oil price slump has contributed further to stock volatility. The sharp decline in oil price is mainly due to agreements between OPEC + members to reduce oil production and the fact that global demand for crude oil has declined dramatically due to the COVID-19 pandemic. In short, the stock market faces dual shocks from the COVID-19 pandemic and oil price changes. With respect to these issues, this study has two primary aims: first, to investigate the impact of COVID-19 on hotel stock market performance; second, to ascertain the impact of commodity price volatility on the hotel stock market.

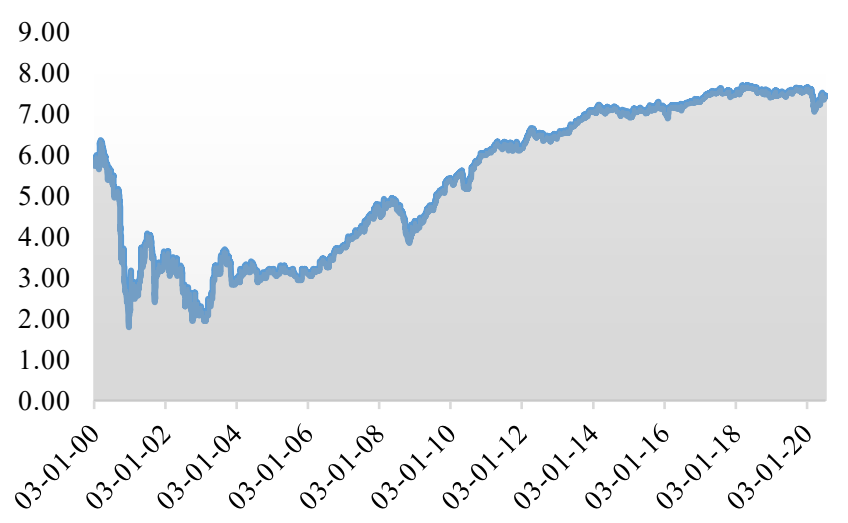

Source: Nasdaq, 2020.

Figure 1: Booking.com Share Price, January 2000-July 2020

\section{Literature Review}

The COVID-19 pandemic has had a tremendous impact on the world economy and has put millions of people as well as jobs at risk. Tourism is among the hardest-hit industries during the pandemic. The hotel industry is one of the most highly interlinked industries in tourism, and almost every part of a hotel's operations from room occupacy rate, staffing plan, and stock price have been affected by COVID-19. The stock market is an interesting topic that has prompted many empirical studies to be carried out from economic and financial perspectives. However, the health crisis has only recently become a topic of interest, and the impact of COVID-19 has not yet been widely analyzed. Additionally, the effect of COVID-19 on international tourism is extremely challenging to estimate, considering the unparalleled and rapidly changing complex nature of the crisis. Thus, the current study will enrich the literature by examining the impact of COVID-19 on the tourism stock market. In previous studies, [4] explored the impact of macroeconomic variables, terrorist attacks, and natural disasters on hotel stock returns. The researchers also pointed out that the SARS outbreak caused a decline in hotel stock returns recorded at an approximate value of $-25.9 \%$, followed by the impactful declines resulting from earthquake $(-22.3 \%)$ and the 9-11 terrorist attacks (-12.5\%). Similarly, [5] analyzed the effect of SARS on fluctuations in Taiwanese hotel stock prices. They also identified that the tourism industry experienced the highest decline in overall stock prices in the Taiwanese Stock Exchange, recording a decline of approximately $28.9 \%$ one month after the SARS outbreak. They indicated that the average hotel stock prices were exposed to above-market risk during the SARS outbreak.

International crude oil price fluctuations have substantial effects on different areas of the financial sector, especially the stock market. In [6], the author investigated the relationship between oil price and performance of the US stock market, identifying a clear adverse link between oil price and stock market performance. Similarly, [7-10] also found evidence of an adverse connection between oil price and stock price. In contrast, [11-13] detected a positive relationship between the oil price and the stock price. In [14], the author stated that oil-exporting countries were positively associated with the stock market, whereas the adverse impact occurred in oil-importing countries. Other key determinants such as gold $[15,16]$, GDP $[17,18]$, exchange rate $[16,18-19]$, and economic crises [10, 20-22] were employed in previous studies.

\section{Methodology}

Instead of using the traditional single-state approach, Markovswitching regression techniques that confirm the validity of crises were applied in this study. A similar approach was applied in different tourism issues by [23-25] with constructive findings. The current study tends to establish the links among different crises and tourism demand forecasting, with tourism stock price as the proxy variable. In examining the behavior of the commodity market towards world tourism performance together with the health crisis, inclusive of COVID-19 as the dummy variable into the regression, remedial measures or precautionary steps can be tackled cautiously for the next crisis occurrence. All the variables were extracted in the high frequency on a daily basis from January 2017 to July 2020 to capture the most recent information. The selected variables comprise the share price of Booking.com as a proxy for world tourism, and the commodity variables are international crude oil price and gold price. Table 1 displays the descriptive statistics of the selected indicators.

Table 1: Descriptive Statistics of the Selected Indicators

\begin{tabular}{lrrr}
\hline & LBOOKING & LBRENT & \multicolumn{1}{c}{ LGOLD } \\
\hline Mean & 7.514 & 4.056 & 7.209 \\
Median & 7.530 & 4.127 & 7.168 \\
Maximum & 7.699 & 4.454 & 7.924 \\
Minimum & 7.049 & 2.197 & 7.048 \\
Standard Deviation & 0.105 & 0.291 & 0.109 \\
Skewness & -1.257 & -2.377 & 1.264 \\
Kurtosis & 5.410 & 10.280 & 4.786 \\
\hline
\end{tabular}

According to [26], the general definition of the piecewise linear switching regression model is as follows:

$$
y_{t}=\sum_{j=1}^{r}\left(\varnothing_{j}^{\prime} q_{t}+\varepsilon_{j t}\right) I\left(c_{j-1}<s_{t} \leq c_{j}\right)
$$


where $q_{t}=\left(w_{t}^{\prime}=y_{t-1}, \ldots, y_{t-p} ; x_{t}^{\prime}=x_{1 t}, \ldots, x_{k t}\right)$ denotes the explanatory variables and observable switch variable [27] interpreted the scheme of switching regression as follows:

$$
y_{t}=\left\{\begin{array}{l}
\beta_{1} \cdot x_{t}+\varepsilon_{t}, \text { when } S_{t}=1 \\
\beta_{2} \cdot x_{t}+\varepsilon_{t}, \text { when } S_{t}=2
\end{array}\right.
$$

where the exogeneous regressors are represented by $y_{t}$ and $x_{t}$, the vector of real numbers is denoted by $\beta_{t}$, the non-observable state variables are shown by $S_{t}$, and the Gaussian white noise by $\varepsilon_{t}$.

The Markov-switching regression model is presented in the following section. The COVID-19 pandemic is captured by a dummy variable with the outbreak detected at the end of 2019.

$$
\begin{gathered}
\text { Booking }_{i, t}= \\
\begin{cases}\beta_{0}^{(1)}+\beta_{\text {Brent }, t}^{(1)}+\beta_{\text {Gold }, t}^{(1)}+\operatorname{Dum}_{\text {COVID-19,t }}^{(1)}+\varepsilon_{t}^{(1)} & S_{t}=1 \\
\beta_{0}^{(2)}+\beta_{\text {Brent }, t}^{(2)}+\beta_{\text {Gold }, t}^{(2)}+\operatorname{Dum}_{\text {COVID }-19, t}^{(2)}+\varepsilon_{t}^{(2)} & S_{t}=2\end{cases}
\end{gathered}
$$

Upon the coefficient determination, the transition probabilities of the regression model were presented to examine the timeframe of the tourism cycle moving from one regime to another. The longer timeframe indicates that a recession might take a longer time to recover from a crisis. The matrix of transition probabilities from one state to another state is presented below:

$$
\pi=\left[\begin{array}{ll}
p_{11} & p_{21} \\
p_{12} & p_{22}
\end{array}\right], p_{x y}=\operatorname{Prob}\left(S_{t}=y \mid S_{t-1}=x\right)
$$

Furthermore, the smoothed and filtered probabilities where $\operatorname{Prob}\left(S_{t}=y \mid y_{1}, \ldots, y_{r}\right)$ can be obtained as well. The graphical illustration of the world tourism cycle detected the reference chronology of crises happening from 2017 to 2020 worldwide. Moreover, the empirical results underwent a series of diagnostic checks for the residuals. The best fit of the model can be determined by the residual diagnostic tests, which include the plot of residuals against a fitted value and the normality probabilities plot for normality distribution testing. Further research can also apply a similar approach to different fields of study.

\section{Results and Discussion}

Hotels play a vital role in the tourism industry and have been categorized as one of the most vulnerable industries during the COVID-19 pandemic. This section discusses the impact of the COVID-19 pandemic and commodity variables on hotel stock price (Booking.com) through a Markov-switching approach. Table 2 reveals that international crude oil price, gold price, and the COVID-19 pandemic significantly affected the share price of Booking.com in both regimes. In regime 1, the international crude oil price and gold price are positively associated with the share price of Booking.com, while the COVID-19 pandemic adversely affected the share price. Oil is one of the most tradeable commodities, and a crash in oil price reflects fear of economic recession. The world economy, including oil-producing countries such as the US, Saudi Arabia, and Iran, has been disrupted due to the COVID-19 pandemic. In addition, the pandemic is also having huge impacts on the tourism industry, manufacturing industry, and factories that consume a large portion of energy in production but have been shut down. Thus, the demand for crude oil has dropped dramatically. Our empirical results show that oil price and stock

\begin{tabular}{|c|c|c|}
\hline \multicolumn{3}{|c|}{ Regime 1: Recession } \\
\hline Variable & Coefficient & $p$-value \\
\hline (Intercept) & 3.142 & $0.000 * * *$ \\
\hline LBRENT & 0.200 & $0.000 * * *$ \\
\hline LGOLD & 0.504 & $0.000 * * *$ \\
\hline COVID-19 & -0.268 & $0.000 * * *$ \\
\hline R-squared & \multicolumn{2}{|c|}{0.855} \\
\hline \multicolumn{3}{|c|}{ Regime 2: Expansion } \\
\hline Variable & Coefficient & $p$-value \\
\hline (Intercept) & 0.582 & $0.000 * * *$ \\
\hline LBRENT & 0.345 & $0.000 * * *$ \\
\hline LGOLD & 0.762 & $0.000 * * *$ \\
\hline COVID-19 & -0.020 & $0.000 * * *$ \\
\hline R-squared & \multicolumn{2}{|c|}{0.847} \\
\hline
\end{tabular}
price move in the same direction. A $1 \%$ decline in oil price weakened the share price of Booking.com by $0.20 \%$ during the COVID-19 pandemic in regime 1, as shown in Table 2.

Table 2: Markov Switching Model Results

Gold acts as a good diversifier and is categorized as a Safe Haven, which is beneficial to investors [28]. Hence, investors feel even more confident when the gold price increases and leads to a rise in stock price. In this study, the results show that gold price is positively associated with stock price, which is consistent with the findings of [15-16]. In regime 1, a percent increase in gold price will lead the share price of Booking.com to rise by $0.50 \%$. As expected, the COVID-19 pandemic had a negative impact on the hotel's stock performance. The results demonstrate that a percent rise in COVID-19 cases will lead to Booking.com's share price to be reduced by $0.27 \%$ during the recession. This negative relationship also implies that tourists feel a high risk to travel because safety is a fundamental condition for international tourists. The values of the adjusted $\mathrm{R}^{2}$ are higher than $80 \%$ in both regimes, signifying that the variability of the dependent variables can be explained accordingly by the selected explanatory variables.

Table 3: Matrix Transition Probabilities

\begin{tabular}{lcccll} 
& Regime 1 & Regime 2 & $\begin{array}{c}\text { Duration } \\
\text { (days) }\end{array}$ & $\boldsymbol{P}$ \\
Regime 1 & 0.985 & 0.015 & 67 & $=\left[\begin{array}{lll}\mathbf{0 . 9 8 5} & \mathbf{0 . 0 1 5} \\
\mathbf{0 . 0 1 5} & \mathbf{0 . 9 8 5}\end{array}\right]$ \\
Regime 2 & 0.015 & 0.985 & 67 & & \\
\hline
\end{tabular}
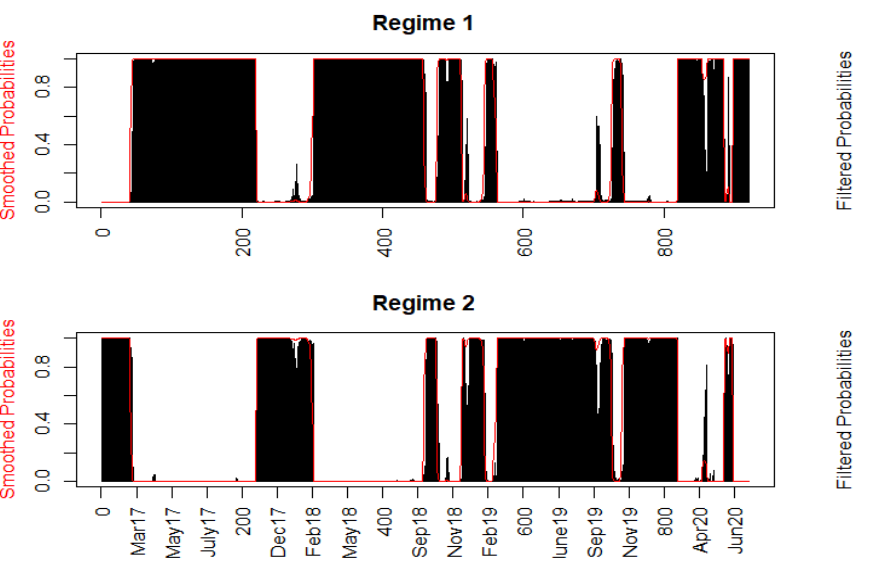

Figure 2. Graphical Illustrations of Smoothed and Filtered Probabilities 
Table 3 demonstrates the two-state transition of matrix transition probabilities. The measurement of the expected duration for the regime-switching period is defined as $1 /\left(1-\mathrm{P}_{00}\right)$, in which the higher transition probability value reveals that it is relatively more difficult to shift from one regime to another. Findings reveal that the model shows $98.5 \%$ to stay in regime 1 , and only with a $1.5 \%$ probability of shifting to regime 2 . Therefore, the expected duration to shift from regime 1 to regime 2 is 67 days during the COVID-19 pandemic. The shorter expected duration results from the matrix transition probabilities illustrates that the potential of another wave of COVID-19 is relatively higher, as the bounce back effect shown in Table 3 is stronger. This may be due to resumed domestic and international economic activities and lifted restrictions on travel and activities.
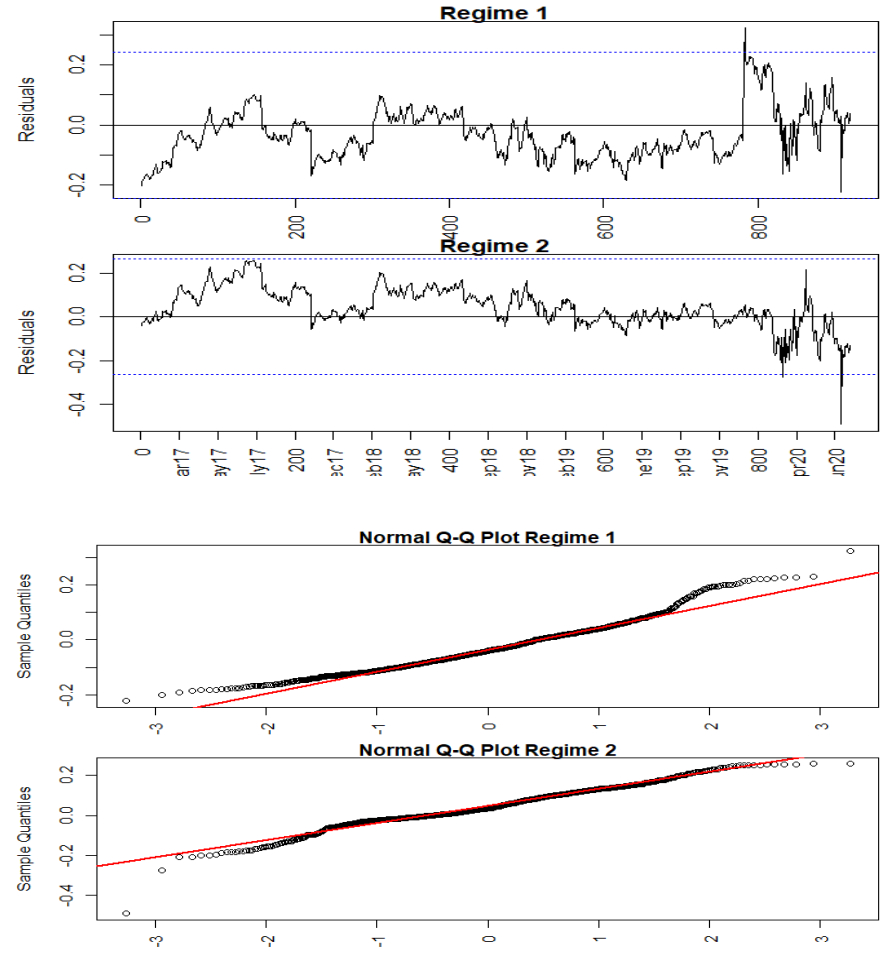

Figure 3. Diagnostic Checking Analysis Outcome

The graphical illustrations of the smoothed and filtered probabilities from the Markov-switching regime model are depicted in Figure 2. A total of six states/shaded areas for the crises were detected, spanning from January 2017 to July 2020. The argument on oil production cutting among oil-producing countries that started in 2017 is well captured in the first shaded area, as illustrated in Figure 2. The second state captured the worst point drop in the history of the Dow Jones in February 2018. In addition, US markets lost nearly USD2 trillion in October 2018, which is identified in the third shaded area, and the fear of US-China trade tension continued in February 2019 and November 2019. Finally, the COVID-19 pandemic is successfully captured in the sixth shaded area. This proves the effectiveness of the Markovswitching approach in detecting economic crises. Figure 3 illustrates that the residuals are considerably fitted against the values. Following the normal Q-Q plot closely, the residuals are like white noise and are moving towards the normal distribution.

\section{Conclusion and Policy Recommendation}

This paper examines the impact of the COVID-19 pandemic on share price of Booking.com through the Markov-switching approach. The empirical findings reveal that the highly contagious disease had negatively influenced hotel stock market performance. Furthermore, a positive associated relationship was identified among international crude oil price, gold price, and stock price. The results also provide strong evidence that the model stays persistent within each regime up to more than $90 \%$. Several economic crises have been captured through smoothed and filtered probabilities under this study. Our findings have several implications. First, they contribute to the current literature regarding the impact of the COVID-19 pandemic on hotel stock performance. Second, the investors have a better understanding of the dynamic relationship between the commodity variables and stock market. Specifically, they are able to adopt more appropriate strategies to safeguard against oil and gold price fluctuations and future crises. Finally, the findings are helpful in providing the government and policymakers with useful insights about the impact of crisis on the stock market, and thus to design a feasible policy to protect the country and society. Further research is needed to fully understand the implications of COVID-19 on the stock market. This would be a fruitful area for further work by taking into account the impact of COVID-19 across different industries. Additionally, future work can utilize different elements and methodologies to gather extra information regarding COVID19 's impact on tourism-related industries.

\section{Conflict of Interest}

The authors declare no conflict of interest.

\section{Acknowledgments}

Financial support from Universiti Malaysia Sarawak is gratefully acknowledged.

\section{References}

[1] UNWTO, "UNWTO world tourism barometer and statistical annex, May 2020”, May 2020. https://www.eunwto.org/doi/abs/10.18111/wtobarometereng.2020.18.1.2\#: :text=Intern ational $\% 20$ tourism $\% 20$ faces $\% 20$ deepest $\% 20$ crisis $\% 20 \mathrm{in} \% 20$ history\&text $=$ Available $\% 20$ data $\% 20$ points $\% 20$ to $\% 20$ a,export $\% 20$ revenues $\% 20$ from $\%$ 20international\%20tourism. Accessed 2 June 2020.

[2] M. Dimitric, I. T. Zikovic, A. A. Blecich, "Profitability determinants of hotel companies in selected Mediterranean countries" Economic ResearchEkonomska Istraživanja, 32(1), 1977-1993, 2019. https://doi.org/10.1080/1331677X.2019.1642785

[3] Booking Holdings, "Booking Holdings reports financial results for 1st quarter 2020", 7 May 2020. https://ir.bookingholdings.com/staticfiles/470e8a97-67db-4d01-b8d5-2ca6c772d0b9. Accessed 5 June 2020.

[4] M. H. Chen, W. G. Kim, H. J. Kim, "The impact of macroeconomic and non-economic forces on hotel stock returns" Hospitality Management, 24, 243-258, 2005. doi: 10.1016/j.ijhm.2004.06.008

[5] M. H. Chen, S. C. C. Jang, W. G. Kim, "The impact of the SARS outbreak on Taiwanese hotel stock performance: An event-study approach" Hospitality Management, 26, 200-212, 2007. https://doi.org/10.1016/j.ijhm.2005.11.004

[6] C. M. Jones, G. Kaul, "Oil and the stock markets" The Journal of Finance, 51(2), 463-491, 1996. https://www.jstor.org/stable/2329368

[7] P. K. Narayan, R. Gupta, "Has oil price predicted stock returns for over a century?" Energy Economics, 48, 18-23, 2015. https://doi.org/10.1016/j.eneco.2014.11.018

[8] X. Luo, S. Qin, "Oil price uncertainty and Chinese stock returns: New evidence from the oil volatility index" Finance Research Letters, 20, 29-34, 2017. doi: 10.1016/j.frl.2016.08.005 
[9] S. Davoudi, A. Fazlzadeh, F. Fallahi, H. Asgharpour, "The impact of oil revenue shocks on the volatility of Iran's stock market return" International Journal of Energy Economics and Policy, 8(2), 102-110, 2018.

[10] A. M. Al-Awaddhi, K. Alsaifi, A. Al-Awadhi, S. Alhammadi, "Death and contagious infectious diseases: Impact of the Covid-19 virus on stock market returns" Journal of Behavioral and Experimental Finance, 27, 100326, 2020. https://doi.org/10.1016/j.jbef.2020.100326

[11] H. C. Bjornland, "Oil price shocks and stock market booms in an oil exporting country" Scottish Journal of Political Economy, 56(2), 232-254, 2009. https://doi.org/10.1111/j.1467-9485.2009.00482.x

[12] C. R. Fang, S. Y. You, "The impact of oil price shocks on the large emerging countries' stock prices: Evidence from China, India and Russia" International Review of Economics and Finance, 29, 330-338, 2014. https://doi.org/10.1016/j.iref.2013.06.005

[13] P. Shahrestani, M. Rafei, "The impact of oil price shocks on Tehran Stock Exchange returns: Application of the Markov switching vector autoregressive models" Resources Policy, 65, 101579, 2020. https://doi.org/10.1016/j.resourpol.2020.101579

[14] K. Shafi, L. Hua, Z. Idress, A. Nazeer, "Oil prices and stock market: Evidence from KSE and BSE" American Journal of Business, Economics and Management, 3(2), 40-44, 2015.

[15] N. Raza, S. J. H. Shahzad, A. K. Tiwari, M. Shahbaz, "Asymmetric impact of gold, oil prices and their volatilities on stock prices of emerging markets" Resources Policy, 49, 290-301, 2016. doi: 10.1016/j.resourpol.2016.06.011

[16] S. Singhal, S. Choudary, P. C. Biswal, "Return and volatility linkages among international crude oil price, gold price, exchange rate and stock markets: Evidence from Mexico" Resources Policy, 60, 225-261, 2019. https://doi.org/10.1016/j.resourpol.2019.01.004

[17] C. H. Puah, T. K. Jayaraman, "Macroeconomic activities and stock prices in a South Pacific Island economy" International Journal of Economics and Management, 1(2), 229-244, 2007. ISSN: 1823-836X

[18] A. K. Giri, P. Joshi, "The impact of macroeconomic indicators on Indian stock prices: An empirical analysis" Studies in Business and Economics, 12(1), 61-78, 2017. https://doi.org/10.1515/sbe-2017-0005

[19] C. Walid, A. Chaker, O. Masood, J. Fry, "Stock market volatility and exchange rates in emerging countries: A Markov-state switching approach" Emerging Markets Review, 12, 272-292, 2011. https://doi.org/10.1016/j.ememar.2011.04.003

[20] C. H. Puah, R. K. Brahmana, K. H. Wong, "Revisiting stock market integration pre-post subprime mortgage crisis: Insight from BRIC countries" Economics and Finance in Indonesia, 61(2), 120-130, 2015.

[21] A. Zopiatis, C. S. Savva, N. Lambertides, M. McAleer, "Tourism stocks in times of crisis: An econometric investigation of unexpected nonmacroeconomic factors" Journal of Travel Research, 58(3), 459-479, 2018. https://doi.org/10.1177/0047287517753998

[22] C. H. Lee, P. I. Chou, "Structural breaks in the correlations between Asian and US stock markets" North American Journal of Economics and Finance, 51, 101087, $2020 . \quad$ https://doi.org/10.1016/j.najef. 2019.101087

[23] K. H. Huarng, T. H. K. Yu, F. S. Parellada, "An innovative regime switching model to forecast Taiwan tourism demand" The Services Industries Journal, 31(10), 1603-1612, 2011. https://doi.org/10.1080/ 02642069.2010.485637

[24] A. N. Soh, C. H. Puah, M. A. Arip, T. H. Kuek, "Oil price and Fijian tourism cycle: A Markov regime-switching model" International Journal of Energy Economics and Policy, 9(6), 1-5, 2019. https://doi.org/10.32479/ijeep.8087

[25] A. N. Soh, C. H. Puah, M. A. Arip, "Tourism forecasting and tackling fluctuating patterns: A composite leading indicator approach" Studies in Business and Economics, 15(2), 192-204, 2020. https://doi.org/10.2478/sbe-2020-0034

[26] T. Terasvita, D. Tjostheim, C. Granger, "Modelling non-linear economic time series: Advance text in econometric" New York, NY: Oxford University Press, 2010.

[27] J. D. Hamilton, "A new approach to the economic analysis of nonstationary time-series and the business cycle" Econometrica, 57(2), 357-384, 1989. https://www.jstor.org/stable/1912559

[28] Z. He, F. O'Gonnor, J. Thijssen, "Is gold a sometime safe haven or an always hedge for equity investors? A Markov-Switching CAPM approach for US and UK stock indices" International Review of Financial Analysis, 60, 30-37, 2018. doi: 10.1016/j.irfa.2018.08.010 